\title{
Soft tissue manipulation for single implant restorations
}
IN BRIEF
- Identifies the importance of soft tissue aesthetics for single implant restorations.
- Details some of the techniques currently available for soft tissue modification of peri-implant tissues.
- Illustrates the advantages and disadvantages of the different techniques available for manipulation and subsequent impression procedures.

\author{
A. Alani' and M. Corson ${ }^{2}$ \\ VERIFIABLE CPD PAPER
}

Achievement of optimal aesthetics on implants in the anterior region can be difficult due to inherent differences to the natural dentition. An important consideration is the peri-implant soft tissues which can be modified to create a more natural emergence profile and contour. The methods with which this can be achieved vary as can methods for recording soft tissue changes and relaying this to technician colleagues. This review appraises some techniques available for the manipulation of the soft tissue profile on single implant restorations.

\section{INTRODUCTION}

The interface between fixed prostheses and soft tissues is important for the success of restorations in the anterior region. ${ }^{1}$ The success rates of implants can be assured as long as appropriate surgical protocols are followed in the presence of adequate quality and quantity of bone. ${ }^{2}$ Unfortunately the presence of adequate bone for implant placement does not always coincide with the ideal soft tissue architecture for an aesthetic result (Fig. 1). This can be considered more significant with the provision of implant restorations replacing multiple tooth units or the solitary implant adjacent to natural teeth especially in patients with a high smile line (Fig. 2). ${ }^{3}$

Where teeth, implants and edentate spaces require restoration, achieving aesthetic harmony can be difficult. In reality the provision of adequate function may be easier to achieve than aesthetics due to a variety of factors. The nature and quality of junctional tissues differ between natural teeth and implants. ${ }^{4}$ As such, creation of an optimal 'emergence profile' on implant retained crowns can be challenging. This

"SpR in Restorative Dentistry, ${ }^{2}$ Consultant in Restorative Dentistry, Department of Prosthodontics, Newcastle Dental Hospital, Richardson Road, Newcastle, NE2 4AZ

*Correspondence to: Dr Aws Alani

Email: awsalani@hotmail.com

\section{Refereed Pape}

Accepted 9 September 2011

DOI: 10.1038/sj.bdj.2011.904

${ }^{\circ}$ British Dental Journal 2011; 211: 411-416

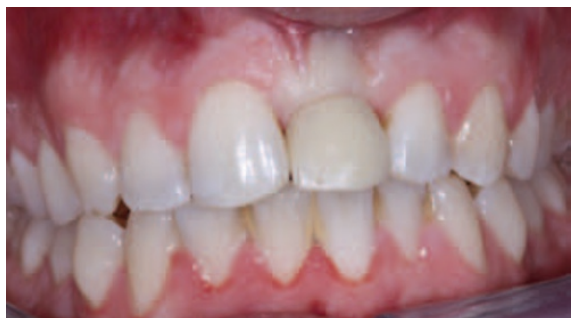

Fig. 1 Single implant restoration (21). Note the gingival blanching, abrupt emergence and poor gingival contour when compared to adjacent teeth

can be compounded when the placement of implants contrasts from the position of natural teeth axially, mesio-distally and bucco-lingually. The difficulties in creating a natural transition between single implant restorations and teeth are primarily associated with the differences in circumferential dimensions, shapes and position (Figs 3-4). Differences in the nature and form of the junctional epithelium between implants and teeth is also an important consideration. Due to these inherent variations the discrepancies in the emergence profiles of teeth and implants are more apparent in the aesthetic zone. In contrast to crowns on natural teeth, implant crown restorations can vary in their depth subgingivally between the implant fixture and the gingival margin. Indeed once implants have fully integrated the connection of a healing abutment is usually the initial stage in emergence development. At abutment connection surgery the majority of healing abutments are cylindrical; this is also a feature of the impression copings and so

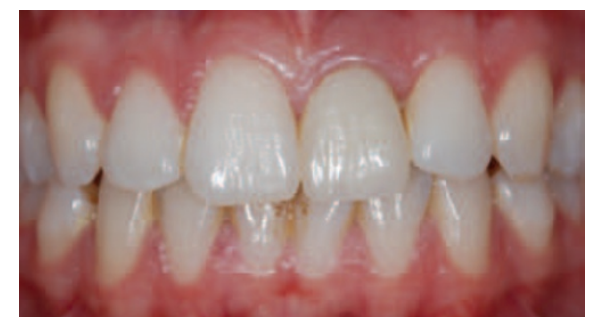

Fig. 2 Definitive restoration on implant 21 subsequent to tissue modification. Note the healthy band of tissue associated with the gingival margin

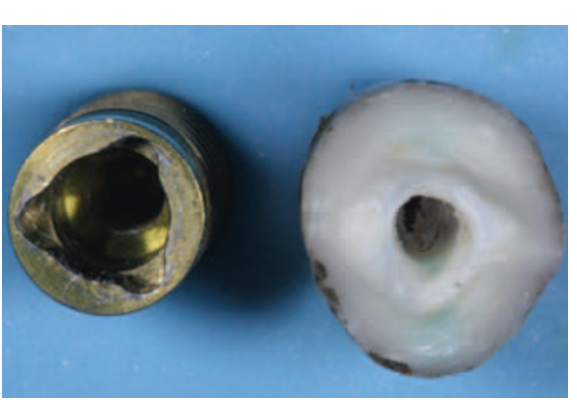

Fig. 3 Circumferentially teeth are inherently ovoid in shape in comparison to implants which are circular

do not simulate the more oval cross section of anterior teeth (Figs 4-5). ${ }^{7}$ Once optimal healing is achieved the soft tissues require manipulation to produce a more oval and funnel shape rather than a cylindrical and parallel emergence which would otherwise be created from the initial impression and subsequent master cast.

Implant restoration emergence can be improved by a period of soft tissue sculpturing before the definitive restoration. ${ }^{8}$ Depending on the depth of the implant and the gingival biotype the potential for 
soft tissue manipulation can differ. Where an implant is placed sufficiently deep in a thick biotype the potential for gradual emergence of the final crown is good. In contrast the potential for manipulation is limited where the implant is shallow to the gingival margin in a thin biotype which can make the emergence profile abrupt and unnatural (Fig. 6). The vertical distance between the implant and the gingival margin is important as the potential for sculpturing is directly proportional to the depth of the implant. ${ }^{9}$ Laboratory duplication of soft tissue profile encircling implant restorations can be achieved using a soft tissue substitute. This attempts to mimic the flexibility of the gingiva which traditional dental stone cannot replicate. The position of the soft tissue around the crowns can be modified in a similar method to those used in orthodontics to rearrange periodontal tissues. ${ }^{10}$ By thinning the crown in the subgingival portion the soft tissues can be brought more coronally, in contrast bulking out the tissues will move them more apically. ${ }^{11}$

\section{TECHNIQUES IN MODIFYING THE EMERGENCE PROFILE OF RESTORATIONS}

\section{Indirect techniques}

There have been a variety of direct and indirect techniques described to manipulate the emergence profile of implant restorations. Macintosh and Sutherland shaped the emergence profile on the master cast by burring the soft tissue substitute before crown construction. ${ }^{12}$ A similar technique has been described where the soft tissue substitute was trimmed away to the desired contour and soft tissue topography of a central incisor. ${ }^{13}$ These techniques have some disadvantages. The soft tissue substitute gives neither the clinician nor the technician an accurate indication of the biotype or the tolerance of the tissue to changes in crown dimension. If the emergence is over contoured tension in the soft tissues may occur causing trauma that may result in recession and even bone resorption.

\section{Direct techniques}

Direct techniques in optimising the soft tissue topography around implants vary in their invasiveness and so trauma to the peri-implant soft tissues. At the abutment

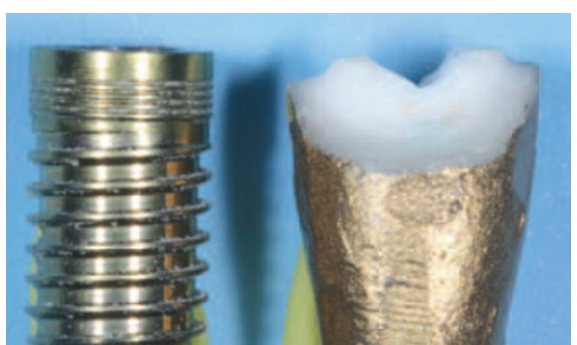

Fig. 4 The cemento-enamel margin of teeth is undulating varying between interproximal areas mesially and distally to the buccal. In comparison the implant restoration margin is circumferentially uniform

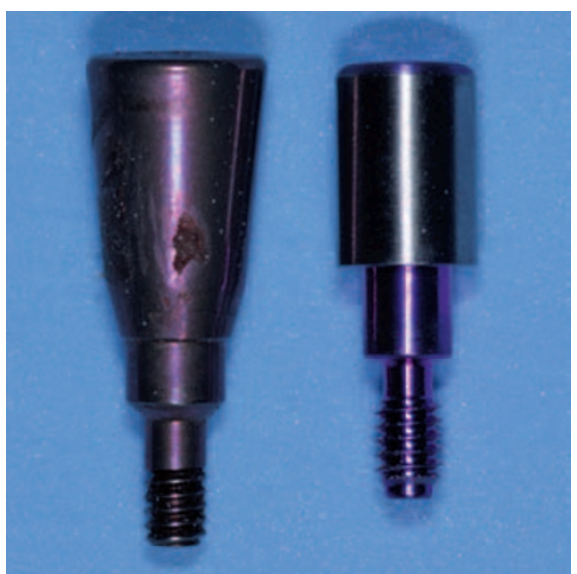

Fig. 5 Two different types of healing abutment. The left abutment has some taper incorporated whereas the right abutment is parallel sided

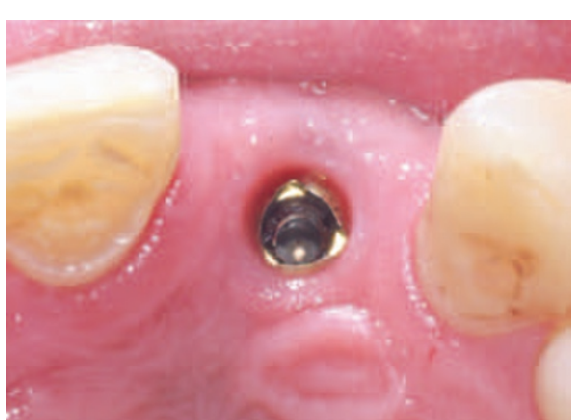

Fig. 6 Superficially placed implant - the scope for emergence and soft tissue modification is limited

connection stage the lifting of a split thickness flap and repositioning on closure has been advocated. ${ }^{14}$ In contrast the use of a fast handpiece with an oval shaped bur has been described to remove circum-implant soft tissue to create optimal emergence. ${ }^{15}$

Less invasive direct techniques involve the modification of a provisional restoration in a gradual manner. This can be considered advantageous as it allows direct assessment of the influence of change in contour on the soft tissue profile. These techniques sculpt the soft tissues by way

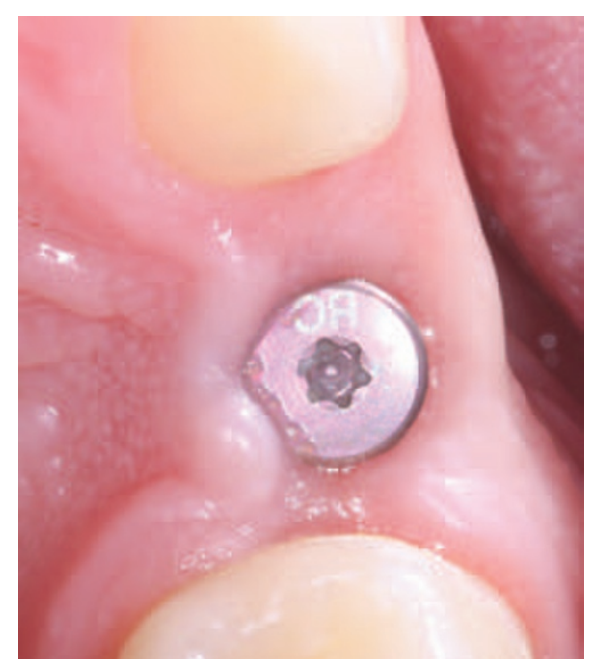

Fig. 7 Implant with healing abutment in the 23 site

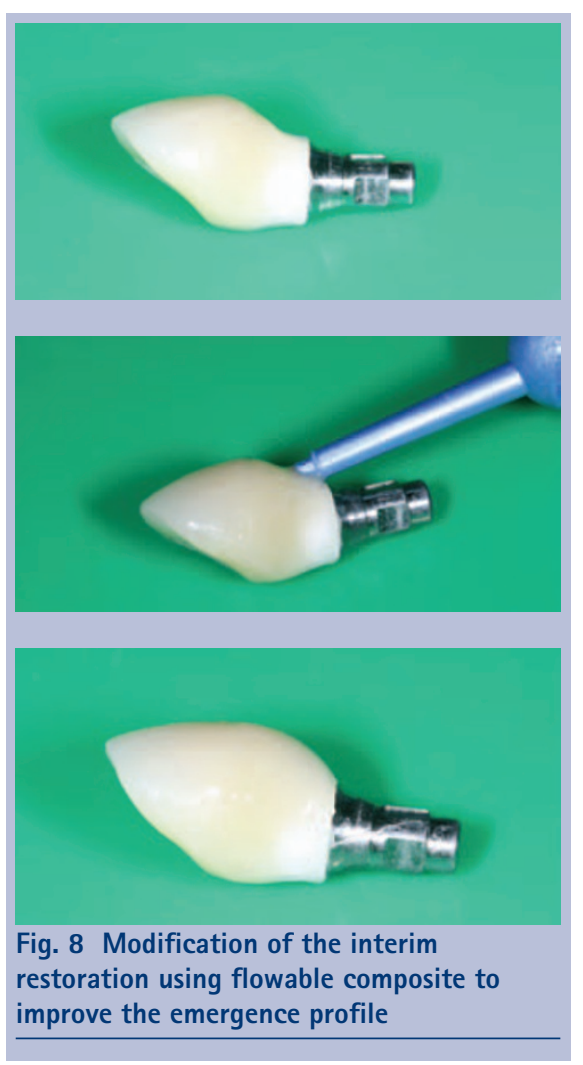

of modification of the interim restoration. The changes in the gingival tissues are then recorded and reproduced in the definitive restoration. Historically autopolymerised resin has been used to modify interim abutments for emergence modification. ${ }^{16}$ The use of resin intra-orally and subgingivally that may have not fully polymerised could cause trauma to tissue that may already be delicate post implant surgery. ${ }^{12}$ This can be overcome with the use of direct composite (Fig. 8). ${ }^{17}$ The use of composite can be considered advantageous due to the material's command, light 


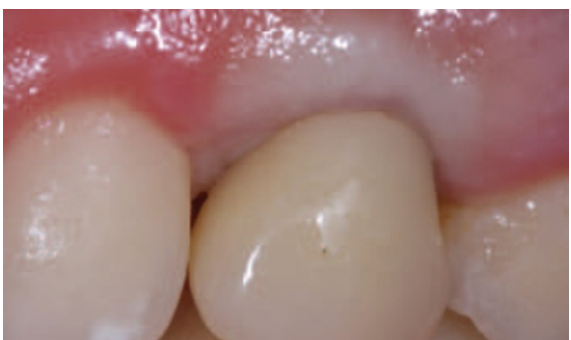

Fig. 9 On torqueing, blanching resulted in the adjacent soft tissues which ceased after 15 minutes

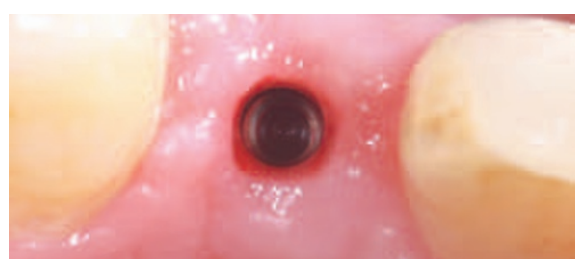

Fig. 10 Virtually parallel emergence profile soon after the healing abutment has been removed to commence the restorative phase

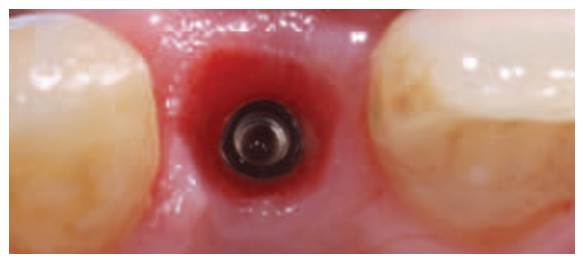

Fig. 11 Emergence profile after eight weeks of modification using flowable composite and an interim restoration. The restoration was modified at initial fit and then again approximately four weeks later

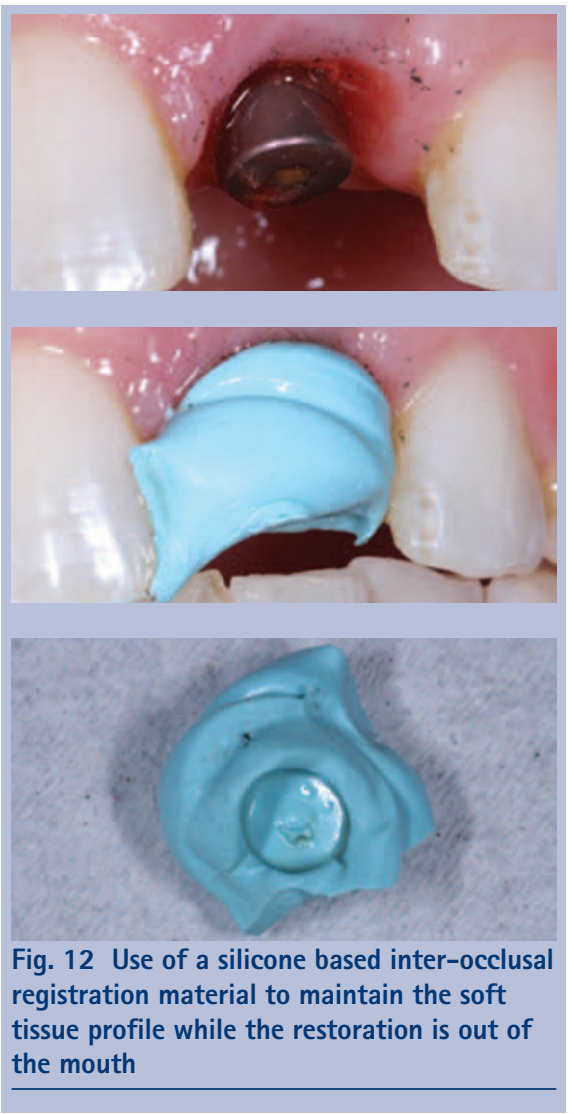

Table 1 Advantages and disadvantages of emergence modification technique

\begin{tabular}{|c|c|c|}
\hline $\begin{array}{l}\text { Soft tissue profile } \\
\text { transfer technique }\end{array}$ & Advantages & Disadvantages \\
\hline $\begin{array}{l}\text { Customised impression } \\
\text { coping }\end{array}$ & $\begin{array}{l}\text { Allows for dimensional changes } \\
\text { that may have occurred to } \\
\text { adjacent teeth to be recorded } \\
\text { eg composite augmentation } \\
\text { procedures. }\end{array}$ & $\begin{array}{l}\text { Second impression required. } \\
\text { Due to the additional stages required may } \\
\text { introduce inaccuracies due to volumetric } \\
\text { changes of materials used. } \\
\text { Requires a short period without the } \\
\text { restoration and may result in soft tissue } \\
\text { collapse. }\end{array}$ \\
\hline $\begin{array}{l}\text { Use provisional } \\
\text { restoration as an } \\
\text { impression coping }\end{array}$ & $\begin{array}{l}\text { Same as customised } \\
\text { impression coping. }\end{array}$ & $\begin{array}{l}\text { Second impression required. } \\
\text { Requires a longer period without the } \\
\text { restoration and may result in soft tissue } \\
\text { collapse. } \\
\text { Patient may go without provisional } \\
\text { restoration during fabrication of definitive } \\
\text { restoration resulting in soft tissue collapse } \\
\text { and the need for development again at } \\
\text { definitive fit. }\end{array}$ \\
\hline $\begin{array}{l}\text { Injection of soft tissue } \\
\text { substitute around } \\
\text { provisional restoration } \\
\text { on master cast }\end{array}$ & $\begin{array}{l}\text { Can be done chairside. } \\
\text { Patient retains provisional } \\
\text { restoration during definitive } \\
\text { restoration instruction. } \\
\text { No need for second impression. }\end{array}$ & $\begin{array}{l}\text { Patient goes without customised } \\
\text { restoration for a short period of time. } \\
\text { Soft tissue substitute may require further } \\
\text { modification to resemble clinical situation. }\end{array}$ \\
\hline
\end{tabular}

set and favourable handling properties. Where direct composite resin is applied to a laboratory made interim restoration the shade matching between the two materials can be difficult although as the shade difference is likely to be subgingival this factor can be considered less crucial. ${ }^{17}$ One notable advantage is the ability to bond to composite incrementally, this is important if the soft tissue cuff is taut and will only allow for gradual modification of emergence over a period of time without undue strain to the gingiva. Where the gingival margin requires more manipulation in the mesial as opposed to the distal portion (or vice versa) composite application can be customised for these differences and can aid in the production on papilla in favourable situations. The use of different types of composite may aid in the sculpturing process. Traditional composite resin can be employed where a significant amount of soft tissue manipulation is required. Where finer adjustments are required flowable composite can be used.

Where gingival blanching occurs due to changes in emergence the restoration can be gradually torqued over a period of 15 minutes (Fig. 9). ${ }^{18}$ Once torqued any residual blanching should ease after 15 minutes. If this doesn't occur the restoration should be removed and dimensions modified to prevent undue trauma as this is likely to reduce control of emergence aesthetics. ${ }^{12}$ Modification of the subgingival portion may therefore take several visits. This soft tissue maturation process may take up to two months depending on the degree of manipulation required. ${ }^{19}$

Where there is a need for implant restoration removal the soft tissues can collapse due to loss of support. This can be overcome by placing an appropriately contoured healing abutment or customised index while the restoration is out of the mouth (Figs 10-11).

The advantages and disadvantages of each technique are outlined in Table 1.

\section{RECORDING SOFT TISSUE CHANGES AND COMMUNICATION WITH TECHNICAL COLLEAGUES}

Once the soft tissue and emergence profile have reached an optimum level the new soft tissue profile needs to be recorded on an implant level working model with appropriate soft tissue substitute for definitive restoration construction. ${ }^{13}$ The production of a new implant level impression and subsequent new master cast is one option, although there are numerous alternatives to this. The record of the new soft tissue profile can take place outside of the clinical environment once the interim restoration has been sterilised. ${ }^{20}$ One option is to place an implant analogue in a dental stone to which the customised restoration is attached. An 


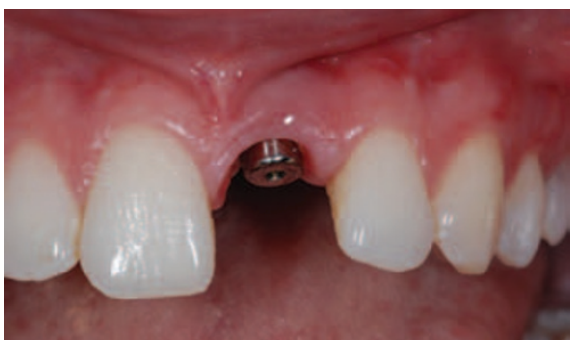

Fig. 13 Customised restoration removed and healing abutment placed

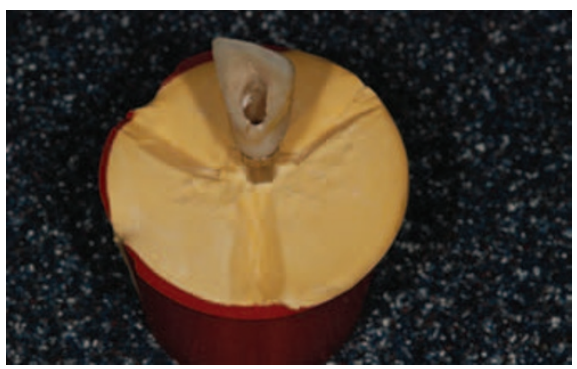

Fig. 14 Customised restoration located onto implant replica embedded in a some laboratory stone

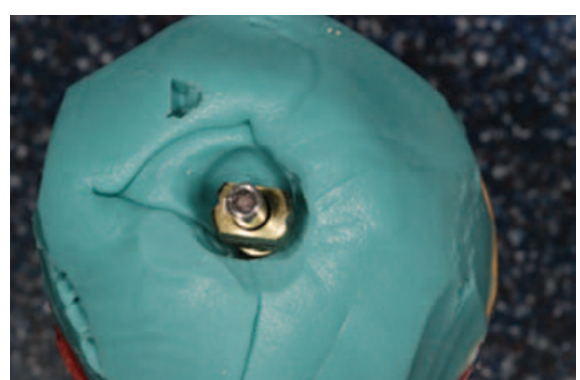

Fig. 15 After putty was applied around the restoration the matrix created was then used to fabricate a customised impression coping with composite

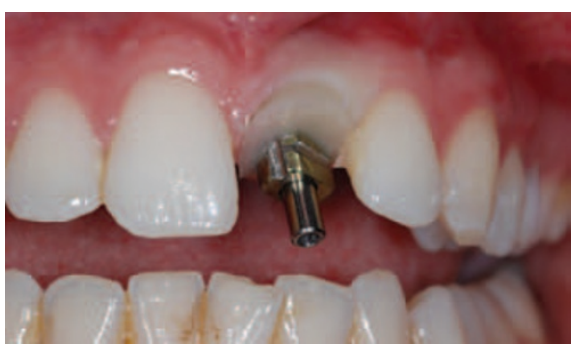

Fig. 16 Customised impression coping in vivo

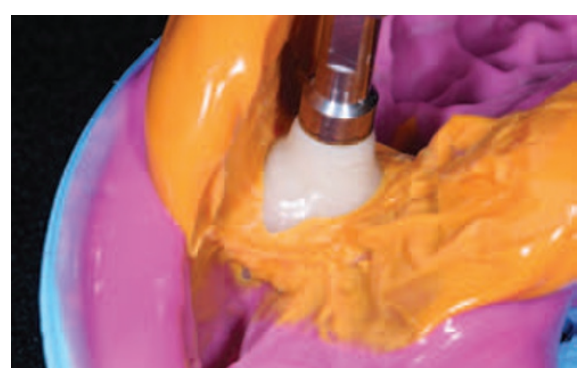

Fig. 17 Relocation of interim crown restoration into a silicone impression subsequent to completion of soft tissue modification. The implant analogue was connected and a new working model produced

Table 2 Advantages and disadvantages of the various soft tissue profile transfer techniques

\begin{tabular}{|c|c|c|}
\hline $\begin{array}{l}\text { Emergence modifica- } \\
\text { tion technique }\end{array}$ & Advantages & Disadvantages \\
\hline $\begin{array}{l}\text { Laboratory modifica- } \\
\text { tion of working model } \\
\text { by way of burring } \\
\text { material away from } \\
\text { around implant replica }\end{array}$ & $\begin{array}{l}\text { Quick and easy. } \\
\text { The clinician and technician can } \\
\text { decide on the optimal emergence } \\
\text { early in the restorative phase. }\end{array}$ & $\begin{array}{l}\text { Gives neither the clinician nor tech- } \\
\text { nician an appreciation of the gingival } \\
\text { biotype. This can result in over-con- } \\
\text { touring of the restoration and so the } \\
\text { development of complications such } \\
\text { as resorption or recession. } \\
\text { An incision may be needed to seat } \\
\text { the temporary with potential for } \\
\text { further recession or resorption. }\end{array}$ \\
\hline $\begin{array}{l}\text { Surgical modification } \\
\text { of peri-implant tissues }\end{array}$ & $\begin{array}{l}\text { Establishes soft tissue profile by } \\
\text { direct manipulation of the tissues as } \\
\text { required. } \\
\text { Can give the clinician the oppor- } \\
\text { tunity to use adjunctive surgical } \\
\text { procedures such as graft placement } \\
\text { to bulk tissues if required. }\end{array}$ & $\begin{array}{l}\text { If conducted at the abutment con- } \\
\text { nection stage the stability of the soft } \\
\text { tissues after healing maybe difficult } \\
\text { to assess. } \\
\text { Further healing and soft tissue } \\
\text { changes may result in suboptimal } \\
\text { definitive restoration. }\end{array}$ \\
\hline $\begin{array}{l}\text { Modification of } \\
\text { emergence profile on } \\
\text { interim restoration } \\
\text { Indexing of implant at } \\
\text { first stage surgery and } \\
\text { subsequent fitting of } \\
\text { optimised temporary } \\
\text { fitted at abutment } \\
\text { connection. }\end{array}$ & $\begin{array}{l}\text { Gives the clinician an opportunity } \\
\text { to gradually modify the restoration } \\
\text { while gauging the effect on the peri- } \\
\text { implant tissues so optimising the } \\
\text { aesthetic result. } \\
\text { Allows soft tissues to mature around } \\
\text { a restoration before providing the } \\
\text { definitive restoration. } \\
\text { Gives the patient opportunity to } \\
\text { trial the restoration with respect to } \\
\text { aesthetics, function and speech. } \\
\text { Avoids multiple visits for modifica- } \\
\text { tion of temporary. }\end{array}$ & $\begin{array}{l}\text { Takes time and visits to reach } \\
\text { the optimal result so elongates } \\
\text { treatment. } \\
\text { Loss of the interim restoration during } \\
\text { the sculpting process can result in } \\
\text { soft tissue regression to previous } \\
\text { dimensions. } \\
\text { Need for index of implant at place- } \\
\text { ment so good primary stability } \\
\text { necessary. } \\
\text { May result in an overcontoured } \\
\text { emergence with potential for reces- } \\
\text { sion and resorption. }\end{array}$ \\
\hline
\end{tabular}

impression of this is taken in silicone and from this a customised impression post is fabricated for the definitive impression (Figs 12-16). ${ }^{20}$ Alternatively the customised restoration itself can be used as an impression coping or relocated into the set impression (Fig. 17). ${ }^{21,22}$ The disadvantage of this technique is that the patient will be without a restoration for some period while a working model is fabricated. The time lapse between model fabrication and reinsert of the interim restoration may result in relapse of the modified soft tissues.

To prevent the need for a delay in reinserting of the interim restoration techniques have been described avoiding the need for a second implant level impression. The placement of the customised restoration on an accurate master cast and the injection of soft tissue analogue around this can recreate the soft tissue profile for fabrication of the definitive prosthesis. ${ }^{23}$ This technique can be achieved at the chairside but the importance of recording the gingival profile and level in addition to the emergence is central to success of the technique (Figs 18-19). Identification of the peri-implant margin intra-orally before transfer to the working model can be achieved using an indelible ink pencil. Intraoral scribing around the margin clinically and, once sterilised, trimming of the soft tissue analogue to this level on the model will complete the registration process (Figs 20-22).

Alternatively a silicone impression of both the interim crown and the soft tissue can be taken. The interim crown can then be relocated into the impression and an implant analogue connected before pouring of the working model. This technique requires the patient to be without the restoration for sometime while the working model is produced.

The use of digital photography to provide technical colleagues with adequate information in shade development has been described. ${ }^{24}$ This practice is also advantageous in recreating optimal restorations for crown emergence. The gingival biotype adjacent to the implant restoration 
can be assessed in addition to papilla dimensions using digital photography.

The advantages and disadvantages of each technique are outlined in Table 2.

\section{ABUTMENT MODIFICATION TO OPTIMISE OUTCOMES}

Where soft tissue profile is suboptimal or the gingival biotype is thin the consideration for modification of the abutment to either improve the gingival tone or relocate the cement lute can be considered. The pink aesthetic score identifies numerous factors in the achievement of the ideal aesthetic gingival profile. ${ }^{25}$ One of these is the colour of the peri-implant mucosa which can be influenced by the depth and position of the implant. Where implant placement is more superficial (and so peri-implant soft tissues are inherently more translucent) the use of gingival toned porcelain directly on the abutment or implant restoration can be considered (Fig. 23). In some cases the cement lute can be relocated supragingivally by way of ceramic pressed directly on the zirconia abutment. ${ }^{26}$ This technique allows the emergence profile to be replicated on the custom abutment while accommodating for continuity of shade between sub and supra gingival portions of the restoration. This technique does have some disadvantages. Ceramic has shown inferior biocompatibility to peri-implant tissues when compared to zirconia and titanium. ${ }^{27,28}$ Relocation of the cement lute supragingivally may result in deterioration over time resulting in microleakage and discolouration.

\section{CONCLUSION}

Where adequate soft tissue mass and favourable biotype is present around a single implant restoration the manipulation of soft tissues to create optimal marginal shape and position can be considered to improve aesthetics of the definitive restoration. This can be achieved in a number of ways and the recording of these changes can also vary. Care needs to be taken not to manipulate the tissues to a degree that would cause undue trauma or prolonged discomfort.

The authors would like to thank Newcastle Dental Hospital Conservation Laboratory for the technical work presented in this manuscript.

1. LeSage B P. Improving implant aesthetics: prosthetically generated papilla through tissue modelling with composite. Pract Proced Aesthet Dent 2006;

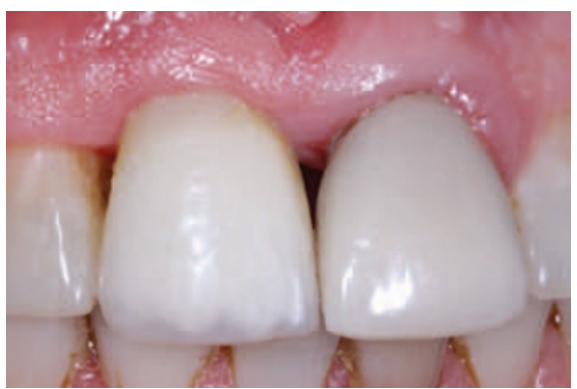

Fig. 18 Implant (11) restored with an interim progressively modified restoration

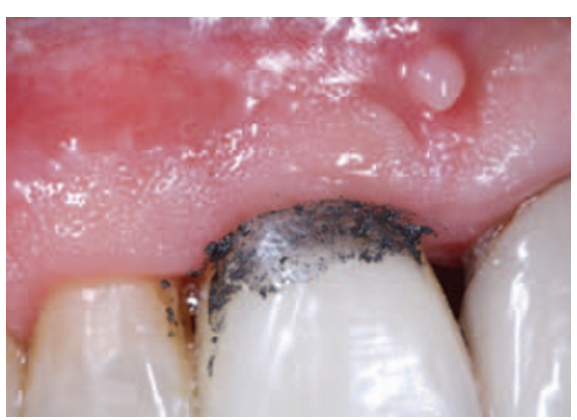

Fig. 19 Indellible ink pencil used to mark gingival margin on crown before removal and relocation on working model

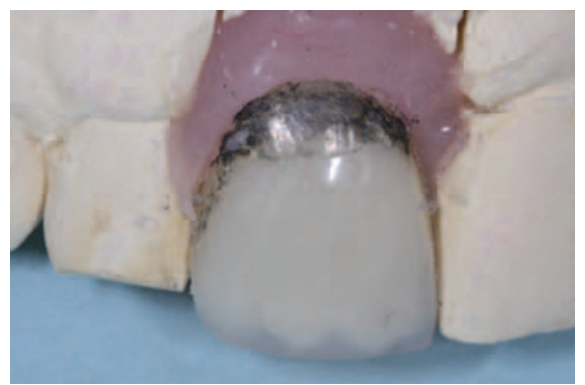

Fig. 20 Gingival substitute applied to model and trimmed to recorded gingival level. Note the soft tissue substitute present on the distal margin which does not represent the clinical situation. This required further trimming before construction of the definitive restoration

18: $257-263$

2. Adell $R$, Eriksson $B$, Lekholm U, Brånemark $P I$, Jemt T. Long-term follow-up study of osseointegrated implants in the treatment of totally edentulous jaws. Int J Oral Maxillofac Implants 1990; 5: 347-359.

3. Alani A, Maglad A, Nohl F. The prosthetic management of gingival aesthetics. Br Dent J 2011; 210: 63-69.

4. Yeung S C. Biological basis for soft tissue management in implant dentistry. Aust Dent J 2008; 53 Suppl 1: S39-S42.

5. McArdle B F, Clarizio L F. An alternative method for restoring single-tooth implants. J Am Dent Assoc 2001; 132: 1269-1273.

6. Belser U C, Grütter L, Vailati F Bornstein M M Weber H P, Buser D. Outcome evaluation of early placed maxillary anterior single-tooth implants using objective esthetic criteria: a cross-sectional, retrospective study in 45 patients with a 2- to 4-year follow-up using pink and white esthetic scores. J Periodontol 2009; 80: 140-151.

7. Bain C A, Weisgold A S. Customized emergence profile in the implant crown - a new technique. Compend Contin Educ Dent 1997; 18: 41-45.

8. Azer S S. A simplified technique for creating a customized gingival emergence profile for

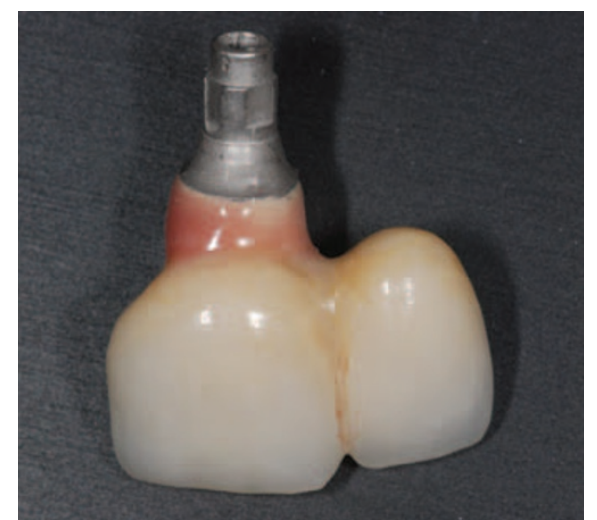

Fig. 21 Implant retained bridge cantilvered from 21 site into 22. Note the pink porcelain glazed onto the subgingival portion

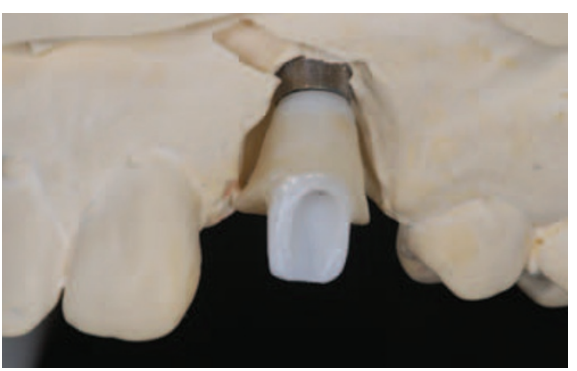

Fig. 22 Ceramic pressed directly onto a zirconia abutment. The dimensions of the subgingival portion were transferred from a previous modified interim restoration

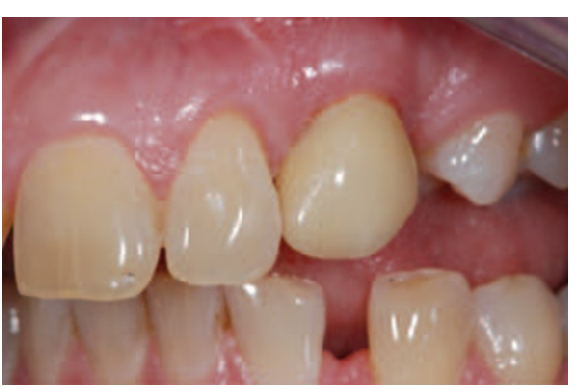

Fig. 23 The final cemented restoration. Note the cement lute line is supragingival

implant-supported crowns. J Prosthodont 2010; 19: 497-501.

9. Stein J M, Nevins M. The relationship of the guided gingival frame to the provisional crown for a single-implant restoration. Compend Contin Educ Dent 1996; 17: 1175-1182.

10. Mihram W L. Dynamic biologic transformation of the periodontium: a clinical report. J Prosthet Dent 1997; 78: 337-340.

11. Biggs $W$ F, Litvak A L Jr. Immediate provisional restorations to aid in gingival healing and optimal contours for implant patients. J Prosthet Dent 2001; 86: $177-180$

12. Macintosh D C, Sutherland M. Method for developing an optimal emergence profile using heat-polymerized provisional restorations for single-tooth implant-supported restorations. J Prosthet Dent 2004; 91: 289-292.

13. Tarlow J L. Procedure for obtaining proper contour of an implant-supported crown: a clinical report. J Prosthet Dent 2002; 87: 416-418.

14. Reikie D F. Restoring gingival harmony around single tooth implants. J Prosthet Dent 1995; 74: 47-50.

15. Davidoff $S R$. Late stage soft tissue modification for anatomically correct implant-supported restorations. J Prosthet Dent 1996; 76: 334-338. 
16. Spyropoulou P E, Razzoog M, Sierraalta M. Restoring implants in the esthetic zone after sculpting and capturing the periimplant tissues in rest position: a clinical report. J Prosthet Dent 2009; 102: 345-347.

17. Al-Harbi S A, Edgin W A. Preservation of soft tissue contours with immediate screw-retained provisional implant crown. J Prosthet Dent 2007 98: 329-332.

18. Kim TH, Cascione D, Knezevic A. Simulated tissue using a unique pontic design: a clinical report. J Prosthet Dent 2009; 102: 205-210.

19. Elian N, Tabourian G, Jalbout Z N et al. Accurate transfer of peri-implant soft tissue emergence profile from the provisional crown to the final prosthesis using an emergence profile cast. J Esthet Restor Dent 2007: 19: 306-314.
20. den Hartog L, Raghoebar G M, Stellingsma K, Meijer H J. Immediate loading and customized restoration of a single implant in the maxillary esthetic zone: a clinical report. J Prosthet Dent 2009; 102: 211-215.

21. Jansen C E. Guided soft tissue healing in implant dentistry. J Calif Dent Assoc 1995; 23: 57-58, 60, 62.

22. Attard N, Barzilay I. A modified impression technique for accurate registration of peri-implant soft tissues. J Can Dent Assoc 2003; 69: 80-83.

23. Neale $D$, Chee W W. Development of implant soft tissue emergence profile: a technique. J Prosthet Dent 1994: 71: 364-368.

24. Amet E M, Milana J P. Restoring soft and hard dental tissues using a removable implant prosthesis with digital imaging for optimum dental esthetics: a clinical report. Int J Periodontics Restorative Dent
2003; 23: 269-275.

25. Fürhauser R, Florescu D, Benesch $T$, Haas R, Mailath $G$. Watzek $G$. Evaluation of soft tissue around single-tooth implant crowns: the pink esthetic score. Clin Oral Implants Res 2005; 16: 639-644.

26. Kamalakidis S, Paniz G, Kang K H, Hirayama H. Nonsurgical management of soft tissue deficiencies for anterior single implant-supported restorations: a clinical report. J Prosthet Dent 2007; 97: 1-5.

27. Abrahamsson I, Berglundh T, Glantz P O, Lindhe J. The mucosal attachment at different abutments. An experimental study in dogs. J Clin Periodontol 1998; 25: 721-727.

28. Welander $\mathrm{M}$, Abrahamsson I, Berglundh T. The mucosal barrier at implant abutments of different materials. Clin Oral Implants Res 2008; 19: $635-641$. 